\title{
TRUMP ve AVRUPA TRANSATLANTIKK DÜZENDE KIRILMA
}

\section{Çağatay ÖZDEMIR*}

Araştırma Makalesi

\section{Özet}

ABD'de Trump dönemiyle birlikte diş politika kararları tartışllmaya başlanmış ve özellikle Beyaz Saray'ın karmaşa içinde olduğu fikri yaygınlaşmıştır. Washington yönetiminin aldığı dış politika kararları çelişkilerle dolu olmuş ve dünya siyasetinde belirsizlikler meydana getirmiştir. Bu durum, Transatlantik ilişkilerde de kendisini göstermiştir. Bu belirsizlik ortamında Trump'ın, Avrupa'ya karşı selefi Obama'ya nazaran sert bir çizgide durması Transatlantik iliş̧kilerde krizler ortaya çıkarmıştır. Yaşanan gelişmeler, Batı'nın artık uluslararası sistemde yekpare bir biçimde hareket etmediği ve ABD ile Avrupa olarak "İki-Batı" şseklinde ayrıştı̆̆ düşüncesini kuvvetlendirmiştir. Bu makale ABD-Avrupa ilişkisinin karakterini ele almuş ve özellikle Trump döneminde bu karakterin yaşadiğl değişimi ortaya koymuştur. Çalışma bu yönüyle, Transatlantik düzenin fay hatlarında bir kirllma meydana geldiğini iddia etmiştir.

Anahtar Kelimeler: ABD, Avrupa, NATO, Transatlantik, Brexit

Trump and Europe: A Fracture in the Transatlantic Order

\section{Abstract}

As Trump came to power, the administration's foreign policy decisions started to be discussed and the idea that the White House was in turmoil became widespread. As these decisions were full of contradictions, many uncertainties followed in world politics. This situation has manifested itself in Transatlantic relations especially when we consider Trump's hardline standing towards Europe when compared to his

* Dr., European Studies, SETA, E-posta: cgtyozdemir@windowslive.com, ORCID ID: 00000001-9477-9761.

Makalenin Gönderilme Tarihi: 14/02/2019 Kabul Edilme Tarihi: 29/03/2019 
predecessor, Obama. Furthermore, these developments have strengthened the idea that the West no longer acts unilaterally in the international system but it is separated between the "Two-Wests": the US and Europe. This article addressed the character of the US-European relationship and, in particular, revealed the change in the character of Trump administration. Lastly, the study argues that a fracture occurred in the Transatlantic order.

Keywords: US, Europe, NATO, Transatlantic, Brexit

\section{Giriş}

Transatlantik ilişkilerin sistemsel ve bölgesel ölçekte dönüşüm geçirmesi ve bunlara ilaveten ittifakın önemine inanmayan liderlerin iktidara gelmesi, ilişkilerin geçmişe oranla daha kırılgan hale gelmesine neden olmuştur. Özellikle Trump'ın ABD Başkanı olmasıyla birlikte, Beyaz Saray'ın yeni patronu, transatlantik ilişkilere yeni bir açılım getirmiş ve Atlantik' in iki yakasında yer alan devletlerarasında başta NATO olmak üzere önemli konularda var olan ciddi görüş ayrılıkları derinleşmiştir. Bahse konu ayrışmalar, Trump'la birlikte yapısal bir karaktere bürünmüş ve farklılaşan tehdit algısı ittifak ilişkisinin düşünsel anlamda da zayıflamasına neden olmuştur.

Bu bağlamda makale, Trump döneminde ABD-Avrupa ilişkisinde ciddi bir kırılmanın gerçekleştiğini iddia etmektedir. Temel argümanı söz konusu kırılmanın dönemsel olduğunun düşünülmesine rağmen, Trump'la birlikte konjonktürel ve yapısal faktörlerin etkisiyle kalıcı bir karaktere dönüşme potansiyeli taşıdığıdır. Transatlantik düzenin yapısındaki dönüşümü değerlendirerek uluslararası sistemde yaşanacak siyasi, ekonomik ve askeri gelişmelere 1 şı tutmak makalenin amacını oluşturmaktadır. İddia edilen kırılmanın kalıcı bir hale dönüşebileceği argümanından hareketle, kapsamlı bir değerlendirme yapabilmek için ABD-Avrupa arasındaki ilişkiler farklı boyutlarıla ele alınacaktır.

Transatlantik düzenin siyasi, iktisadi ve güvenlik boyutu, ABD’nin dış politika anlayışını ortaya koyan Ulusal Güvenlik Strateji Belgesi ve Trump'ın uluslararası zirvelerdeki açıklamaları üzerinden söylemsel ve kurumsal çerçevede ele alınacaktır. Bu noktada ilk olarak ABD-Avrupa ilişkisinin karakteri tarihsel bir bağlamda değerlendirilecektir. Sonrasında Trump'ın Transatlantik düzenine yaklaşımı ve söz konusu düzenin devamını sağlayan başta NATO olmak üzere uluslararası kuruluşlara bakışı ele alınacaktır. 
Bununla birlikte, Trump'ın Transatlantik düzende yarattığı kırılmanın Avrupa'daki yansımaları AB Merkez Ordusu, Brexit tartışması ve Avrupa içindeki güç parçalanması temelinde incelenecektir. Son olarak Transatlantik düzenin en önemli unsurlarından biri olan ekonomik ilişkiler söz konusu kırılmanın önemli bir parçası olarak ele alınacaktır.

\section{Transatlantik Düzenin Karakteri}

$A B D$ ve Avrupa arasındaki köklü ilişkilerin günümüzde eriştiği seviyeyi ve bu ilişkilerin karakterini anlamak için söz konusu iki aktör arasındaki ilişkilerin tarihsel arka planını değerlendirmek gerekmektedir. Avrupa'nın Kuzey Amerika'daki etkisi İngiliz kolonileri üzerinden gelişmiştir. İngilizlerin vatandaşlarını Kuzey Amerika'ya yerleştirmesi sonucu 1700'lerde Kuzey Amerika'daki on üç İngiliz kolonisinde yaklaşık olarak 400 bin kişi hayatını sürdürmüştür. Koloniler kuruluşlarından itibaren Britanya İmparatorluğu'nun ve dolayısıyla Atlantik ticaret toplumunun ayrilmaz bir parçası olmuştur. Birleşik Krallığa tütün, kereste ve diğer tarımsal ürünleri satarken, karşılığında sanayi ürünleri satın almıştır. Britanya Fransa ile savaş halindeyken bile koloniler yasadışı bir şekilde Fransa hâkimiyetindeki Kanada ile ticaret yapmaya devam etmiştir. Birleşik Krallığın merkantilist ${ }^{1}$ denizcilik yasasından (Navigation Act) birçok şekilde yararlanarak Karayip adalarındaki Fransız ve Hollanda sömürgeleri ile karlı bir ticaret geliştiren koloniler, söz konusu ticareti kısıtlayıcı çabalara ise şiddetle karşı çıkmıştır. ${ }^{2}$

$\mathrm{Bu}$ bağlamda, ABD'nin bağımsızlık ilanından önce serbest ticaretin lideri haline gelen 13 koloni kayda değer derecede zenginleşmiş ve Kuzey Amerika'da yaşayan topluluklar arasında yeni bir sosyal sinıf meydana gelmiştir. Söz konusu zenginleşmenin olumlu etkisiyle ve Birleşik Krallığın Yedi Yıl Savaşları'ndan sonra yeni vergiler koyması neticesinde koloniler Birleşik Krallık’tan kopma eğilimi göstermişlerdir. ${ }^{3}$ Kuzey Amerika'daki

1 Merkantalizm Avrupa'da 16.yy ile 18.yy ortalarına kadar sürmüş, 300 yıl uygulanan bir iktisar politikasıdır. Ekonomik servet veya anapara devletin elinde tuttuğu, altın, gümüş miktarı veya ticari değer ile temsil edilir. Merkantilizme göre, yönetim ekonomide korumac1 bir rol oynamalı, dış satımı desteklemeli ve dış alımı sınırlandırmalıdır. Bu fikirler üzerinde duran ekonomik sisteme merkantilist sistem denir. Ayrıntılı bilgi için bkz. George C. Herring, From Colony to Superpower: U.S. Foreign Relations Since 1776 (New York: Oxford University Press, 2008), 12-16-21.

2 Herring, From Colony to Superpower, 320.

3 J.M. Roberts, Avrupa Tarihi, çev. Fethi Aytuna (İstanbul: İnkılap Yayıncılık, 2015), 391392. 
ortaya çıkan bu güçlü sosyal sınıf, çok geçmeden Birleşik Krallık'tan bağımsızlığını kazanmak adına harekete geçmiştir. On üç koloni, Thomas Jefferson ve George Washington öncülüğünde birleşerek, 4 Temmuz 1776 tarihinde Bağımsızlık Bildirgesini yayınlamışlardır. $\mathrm{Bu}$ bildirgede, Amerika'da Birleşik Krallık'ın otoritesinden bağımsız bir ülkenin kurulduğu ilan edilmiştir. ${ }^{4}$

1776-1783 yılları arasında 13 koloninin Birleşik Krallık'a karşı verdiği mücadele sonucunda elde edilen bağımsızlık, ABD'ye Avrupa diplomasisi konusunda bazı gerçekleri göstermiştir. Avrupa devletlerinin tutumları bir buçuk yüzyıla yakın bir süre ABD'nin Avrupa politikasına bulaşmamasına ve kendini korumak için Avrupa'dan uzaklaşmasına sebep olmuştur. Monroe Doktrini ile çerçevesi çizilen Avrupa'nın savaşlarına dahil olmaktan kaçınma anlayışı esasında Başkan George Washington döneminden başlayarak benimsenmiştir. ${ }^{5} \mathrm{Bu}$ anlayışın temelinde ABD'nin askeri ve ekonomik zayıflığı olmakla birlikte büyük güçlerin rekabetinde zarar görmekten kaçınma arzusu da önemli bir rol oynamıştır. Doktrin aynı zamanda Avrupa'nın da Amerika kıtasının içişlerine müdahale etmemesini öngördüğü için Eski Dünya'nın Yeni Dünya üzerindeki egemenliğini sona erdirmiş ve Batı yarıküredeki 300 yıllık Avrupa sömürgeciliğine de son vermiştir. ${ }^{6}$

ABD’nin Fransız Devrimi ve devam eden süreçte Avrupa içindeki çatışmaların içine yoğun olarak dahil olmaması kendisi için bir avantaj teşkil etmiştir. Bu sayede 19. yüzyılın geri kalanında ABD dış politika stratejisini kıtada egemenliğini yayma ve Avrupalı güçleri kıtadan uzak tutma üzerine kurmuştur. $^{7}$

Washington'un bu tercihleri, ülkenin gücünü giderek artırmıştır. ABD'nin gücünü artırması ise Avrupa'ya karşı mesafeli tavrında değişime sebep olmuştur. $\mathrm{Bu}$ dönemde, Transatlantik ilişkilerde bir yakınlaşma

4 Declaration of Independence: A Transcription, National Archives. Bildiri, İnsanların eşit doğduğuna ve doğuştan gelen yaşama, özgürlük ve mutluluğu arama (doğal haklar) haklarının bulunduğunu ifade etmektedir. Bu yönüyle, herhangi bir hükümet şeklinin bu haklara zarar vermemesi gerektiği belirtilmiştir. Bağımsızlık Bildirgesine göre, eğer ki bir zarar meydana gelirse o hükümeti değiştirmek ve yeni bir hükümet kurmak halkların meşru hakkıdır.

5 Richard D. Hooker, Jr, "The Grand Strategy of the United States”, INSS Monograph, Ekim, 2014, 1-2.

6 Walter LaFeber, “The US Rise to World Power" içinde US Foreign Policy, ed. Michael Cox ve Doug Stokes (Oxford: Oxford University Press, 2008), 48.

7 Hooker, "The Grand Strategy," 2. 
beklentisi oluşmuştur. Fakat ABD gücünü artırdıktan sonra savaş riskini göze almış ve yakınlaşma beklentisi yerini çatışmaya bırakmıştır. Bu durumun önemli bir göstergesi, 1898 yılında yaşanan ABD-İspanya savaşıdır. Savaşın sonucunda galip gelen ABD'nin küresel pozisyonu önemli ölçüde değişmiştir. Guam ile Porto Riko'nun da dahil olmasıyla denizaşırı topraklara sahip olan ve sonrasındaki süreçte Japonya'nın dünyaya açılmasına da öncülük eden Washington, artık bir Pasifik gücü haline gelmiştir. Uluslararası arenadaki bu yeni konumu ABD'ye Avrupa'da belirleyici bir rol oynama olanağı vermiştir. ${ }^{8}$

ABD’nin artan güc $\ddot{a}^{9}$ Transatlantik ilişkilerin karakterini belirlemiş, bu durum Birinci ve İkinci Dünya Savaşı sırasında önemli bir faktör olmuştur. Washington'ın her iki dünya savaşına da girmek zorunda kalarak dahil olması söz konusu savaşların sonlanmasını hızlandırmıştır. Yükselen profiline rağmen 1823 'ten itibaren izolasyonist güdülerle hareket eden $\mathrm{ABD}$ için, Birinci Dünya Savaşı her ne kadar Avrupa kıtasında yaşanan bir sorun olarak görülse de ülkenin çıkarları bağlamında tehlike arz etmiştir. Öyle ki, bu dönemde Almanya'nın gücünü giderek küresel bir seviyeye taşıması ve ittifaklarını artırması söz konusu tehlikelerin başında gelmiştir. Dolayısıyla, Atlantik'in iki yakasında bulunan müttefikler arasında kolektif güvenliğin sağlanması gündeme gelmiştir. Keza, Birinci Dünya Savaşı'nın sona ermesiyle birlikte, uluslararası güvenliğin sağlanmasını hedefleyen ve fikir babasının ABD Başkanı Woodrow Wilson'ın olduğu Milletler Cemiyeti kurulmuştur. $\mathrm{Bu}$ girişimlere ve özellikle ABD Başkanı Wilson'ın tüm çabalarına rağmen ABD'nin Milletler Cemiyeti'ne girmemesi neticesinde Transatlantik ilişkilerde arzulanan yakınlık tesis edilememiştir. Hatta İkinci Dünya Savaşı'nın yaşanması kolektif güvenliğin tekrar gözden geçirilmesini gerektirmiştir. ${ }^{10}$

İkinci Dünya Savaşı sonrası dönemde Transatlantik ilişkiler yakınlaşmış ve bu gelişmeye binaen ABD'nin de dâhil olduğu yeni bir kolektif güvenlik sistemi kurulması öngörülmüştür. Savaşın ardından dünya barışını,

8 Herring, From Colony to Superpower, 177.

9 Ekonomik olarak ABD eşitler arasında birinci duruma gelmiştir. Kişi başına gelirde dünyanın en büyüğü haline gelen ABD'de ulusal zenginlik 1900-1912 yılları arasında ikiye katlanmıș, tarımsal ve endüstriyel üretim tavan yapar hale gelmiştir. Bu konu hakkında daha fazla bilgi için bkz. Herring, From Colony to Superpower, 340.

10 Charles A. Kupchan, "The Fourth Age: The Next Era in Transatlantic Relations", The National Interest, no:86 (2006): 79. 
güvenliğini korumak ve uluslararasında ekonomik, toplumsal ve kültürel işbirliği oluşturmak için Birleşmiş Milletler kurulmuştur. Söz konusu girişimlerin varlığına rağmen uluslararası sistem yeni bir mücadeleye sahne olmuştur. Bahse konu mücadele Washington ve Moskova arasında yaşanmış ve iki kutuplu bir dünya düzenini meydana getirmiştir. Anılan iki kutbun, Avrupa özelinde yoğun şekilde mücadele verdiği yer ise Doğu Avrupa olmuştur. ${ }^{11}$

Savaşın ardından Almanya'nın ikiye bölünmesiyle birlikte ABD, Avrupa'daki gücünü korumaya odaklanmıştır. ${ }^{12}$ Böylece Transatlantik ilişkilerin karakteri kolektif savunmaya dayalı yakın işbirliğine dönmüştür. Bu bağlamda, ABD öncülüğünde Sovyet Sosyalist Cumhuriyetler Birliği’ni (SSCB) durdurmak amaçlı kurulan Kuzey Atlantik Anlaşması Örgütü (NATO), Avrupa'daki kolektif savunma anlayışının yapı taşını oluşturmuştur. ${ }^{13}$

Tablo I: Atlantik Düzeni, 1776-2001 14

\begin{tabular}{|c|c|c|c|c|}
\hline & $\begin{array}{l}\text { Etkileşim } \\
\text { Biçimi }\end{array}$ & Çıkarlar & Kimlik & $\begin{array}{c}\text { Düzenin } \\
\text { karakteri }\end{array}$ \\
\hline $\begin{array}{l}1776- \\
1905\end{array}$ & $\begin{array}{c}\text { Güç } \\
\text { Dengesi }\end{array}$ & $\begin{array}{l}\text { Ayrık ve } \\
\text { dağınık }\end{array}$ & Karş1 & Askeri rekabet \\
\hline $\begin{array}{l}1905- \\
1941\end{array}$ & $\begin{array}{c}\text { Tehdit } \\
\text { Dengesi }^{15}\end{array}$ & $\begin{array}{c}\text { Ayrık bazı } \\
\text { durumlarda } \\
\text { yakın }\end{array}$ & Uyumlu & $\begin{array}{c}\text { Barışç1l birlikte } \\
\text { yaşama }\end{array}$ \\
\hline $\begin{array}{l}1941- \\
2001\end{array}$ & $\begin{array}{l}\text { İşbirlikçi } \\
\text { Güvenlik }\end{array}$ & Ortak & Paylaşımlı & $\begin{array}{l}\text { İttifak/Güvenlik } \\
\text { birliği }\end{array}$ \\
\hline
\end{tabular}

11 Marc Trachtnberg, A Constructed Peace, the Making of the European Settlement 1945-1963 (New Jersey: Princeton University Press, 1999), 4.

12 Trachtnberg, A Constructed Peace, 21-22.

13 David Frum, “Trump's Trip Was a Catastrophe for U.S.-Europe Relations”, The Atlantic, 2017.

14 Kupchan, "The Fourth Age: The Next Era in Transatlantic Relations", 78.

15 Güç dengesi uluslararası sistemde aşırı güçlenen bir devletin diğer devletler tarafindan dengelenmesini ifade etmektedir. Öte yandan Stephen Walt tarafından ilk kez 1985 yılında "Alliance Formation and the Balance of World Power" isimli makalede tehdit dengesi kavramı ortaya konmuştur. Walt'a göre uluslararası sistemde bir devletin aşırı güçlenmesi diğer devletlerin ittifak oluşumuna giderek dengeleme yapması için yeterli değildir. Devletlerin diğer devletlere yönelik tehdit algılamaları bu noktada belirleyici rol oynar. 
Kolektif güvenlik Transatlantik ilişkilerin tek belirleyicisi olmayıp, farklı unsurların etkileri de bulunmaktadır. Nitekim Atlantik'in iki yakasındaki ilişkileri konjonktürel faktörler ve uzun vadeli yapısal etkiler ile eğilimler ciddi şekilde etkilemektedir. Bu durumu aşağıdaki tablo üzerinden göstermek mümkündür.

Tablo II: Transatlantik İlişkileri Etkileyen Faktörler ${ }^{16}$

\begin{tabular}{|c|c|c|}
\hline & $\begin{array}{c}\text { Konjonktürel } \\
\text { Faktörler }\end{array}$ & $\begin{array}{l}\text { Uzun Vadeli Yapısal } \\
\text { Etkiler ve Eğilimler }\end{array}$ \\
\hline $\begin{array}{l}\text { Transatlantik’te } \\
\text { Yakınlaşma }\end{array}$ & & $\begin{array}{c}\text { Coğrafya, } \\
\text { Kaynaklar (Endüstriyel } \\
\text { materyaller ve su kaynakları) }\end{array}$ \\
\hline Statüko & Diş tehdit & $\begin{array}{c}\text { Tarih, } \\
\text { Büyük güçlerin politikaları, } \\
\text { Kamuoyunun etkisi }\end{array}$ \\
\hline $\begin{array}{c}\text { Transatlantik’te } \\
\text { Uzaklaşma }\end{array}$ & $\begin{array}{c}\text { Devletlerin } \\
\text { Kapasiteleri, } \\
\text { Politik kutuplaşma, } \\
\text { Liderlerin kişilikleri, } \\
\text { Ekonomi }\end{array}$ & $\begin{array}{c}\text { Nüfus, } \\
\text { Kaynaklar (Besin ve Enerji), } \\
\text { Uluslararas1 Kurumlar. }\end{array}$ \\
\hline
\end{tabular}

İkinci Dünya Savaşı'ndan beri ekonomik, toplumsal ve kültürel işbirliğinin yanı sıra güvenlik temelinde süregelen ilişkiler, SSCB'nin dağılmasıyla dönüşüm geçirmiştir. Kızıl Ordu tehdidinin ortadan kalkmasıyla ABD korumasına artık ihtiyacı kalmadığını düşünen Avrupa'nın, ABD'ye yönelik tutumunda değişiklikler belirmiştir. ${ }^{17}$ Soğuk Savaş'ın bitişi ABD'nin de Avrupa'ya ve Avrupa entegrasyonuna bakışında önemli değişiklikler meydana getirmiş, Avrupa Topluluğu'ndan AB'ye geçiş sürecinde ortaya çıkan gelişmeler Transatlantik ilişkilerin belirleyicisi olmaya başlamıştır. Avrupa Birliği’nin kurulmasıyla birlikte; ekonomi, savunma ile güvenlik ve dış politika alanlarında ortak politikalar geliştirilmeye başlanması ilişkilerde

16 Xenia Wickett, "Transatlantic Relations Converging or Diverging?", Chatham House Report, 2018.

17 Thomas H. Henriksen, Cycles in US Foreign Policy since the Cold War (California: Palgrave Macmillian Press, 2017), 150. 
belirsizlikler ve çelişkilerin de hakim olduğu yeni bir döneme geçilmesine neden olmuştur. ${ }^{18}$

Transatlantik ilişkilerdeki kökten değişim ise, 1990'ların sonuna doğru meydana gelmiştir. Maastricht Antlaşması, diğer adıyla Avrupa Birliği Antlaşması'nın, 1 Kasım 1993 tarihinde yürürlüğe girmesiyle yukarıda sözü edilen alanlardaki politikalar somutlaşmaya başlamıştır. 1999'a kadar parasal birliğin tamamlanmasına, Avrupa vatandaşlığının oluşturulmasına ve ortak dış ve güvenlik ile adalet ve içişlerinde işbirliği politikalarının meydana getirilmesine karar verilmiştir. Bu bağlamda, artık ABD ile Avrupa arasındaki bakış açıları farklılaşmaya başlamış ve Batı kimliğindeki yekpare tutum giderek ayrışmıştır. ${ }^{19} \mathrm{Bu}$ süreci müteakip Clinton, Bush ve Obama dönemlerinde Transatlantik ilişkiler zaman zaman büyük sınavlardan geçmek durumunda kalmıştır. Bahse konu görüş ayrılıklarının en belirgin şekilde görüldügü olaylardan biri 11 Eylül 2001 terör saldırısından sonra gerçekleşen Irak Savaşı'dır. Transatlantik işbirliğinin çok daha sorgulanır hale gelmesine neden olan Irak Savaşı'nda, ABD ve AB'nin ayrı politikalar gütmesi var olan görüş ayrılıklarını daha da arttıran bir gelişme olmuştur. ${ }^{20}$ Esasında Irak Savaşı nezdinde sadece ABD-AB ekseninde bir kırılma yaşanmamış, AB'nin kendi içinde de bir bölünme meydana gelmiştir. İngiltere, İtalya ve Doğu Avrupa ülkeleri ABD'ye destek olurken, Fransa, Almanya ve Kuzey Avrupa ülkeleri ABD'nin karşısında yer almıştır. ${ }^{21}$ Obama döneminde 2008 yılındaki mali krizin yansıması olarak ABD-Almanya ilişkilerinde finans öncelikleri tartışmaya açılmış ${ }^{22}$ olmakla birlikte, Bush dönemine nazaran Transatlantik ilişkilerde yakınlaşma meydana gelmiştir.

ABD-Avrupa ilişkilerinde farklı dönemlerde yaşanan ve yukarıda da bahsedilen ciddi sınamalara rağmen transatlantik ilişkiler genel olarak bakıldığında olumlu bir seyir göstermiştir. Washington Avrupa entegrasyon sürecini başından itibaren desteklemiş ve Transatlantik ilişkilerin gelişmesi adına Avrupa'da istikrar ve refahın artması taraftarı olmuştur. ${ }^{23} \mathrm{ABD}$-Avrupa

18 Mike Smith, "The USA and the EU" içinde US Foreign Policy, ed. Michael Cox ve Doug Stokes (Oxford: Oxford University Press, 2008), 252.

19 Kupchan, "The Fourth Age," 77

20 Smith, "The USA and the EU," 252.

21 Joseph S. Nye. Jr, "US Power and Strategy After Iraq", Foreign Affairs, Temmuz/Ağustos 2003, https://www.foreignaffairs.com/articles/united-states/2003-07-01/us-power-and-strategyafter-iraq

22 Frum, "Trump's Trip."

23 Smith, "The USA and the EU," 240-242. 
ilişkilerinde konjonktürel ve yapısal açıdan ortak siyasi ve ekonomik çıkarların varlığı da bahse konu sınamaların aşılmasını ve ilişkilerin sağlıklı bir şekilde devam etmesini sağlamıştır. Ancak transatlantik ilişkilerin Obama dönemindeki olumlu seyri, Donald Trump'ın ABD Başkanı olarak seçilmesinden sonra ilişkileri etkileyen konjonktürel ve yapısal faktörlerin farklılaşmasıyla tersine dönmüş̧ür.

\section{Transatlantik İlişkilerde Dönüşüm}

ABD'nin dış politikasında yaşanan söz konusu konjonktürel ve yapısal değişimler transatlantik ilişkilerde taraflar arasında ciddi kırılmaların meydana gelmesine yol açmış ve aynı zamanda uluslararası sistemde kayda değer değişikliklere neden olmuştur. Bu bağlamda, uluslararası sistemin hangi temeller ve dengeler üzerinden şekilleneceği sorusu Transatlantik ilişkilerin gidişatını anlayabilmek için önem arz eder hale gelmiştir. Nitekim dünya düzeninin gelecekte Amerikan liderliğinde liberal hegemonik bir yapıs1 olmayacağı yönünde pek çok ciddi argüman ileri sürülmüş ve bu da Amerikan dünya düzeninin yerini neyin alacağı yönünde sorulara yol açmıştır.

Uluslararası sistemde yaşanan gelişmeler sebebiyle ABD'nin uyguladığ 1 hegemonik liberal düzenin değişmekte olduğu görülmektedir. Örneğin bu çerçevede Mearshimer güçlü bir devletin sadece, tek kutuplu bir sistemde kendine yönelik tehditlerle karşılaşmadığında liberal hegemonik bir anlayışı uygulayabileceğini öne sürmüştür. İki kutuplu ya da çok kutuplu bir uluslararası sistem söz konusu olduğunda ise güçlü bir devletin realist bir anlayışla hareket etmek zorunda olduğunu iddia etmiştir. Bu noktada Çin'in etkileyici yükselişinin tek kutuplu sistemin bitişini işaret eden en temel neden olarak göstermiştir. ${ }^{24}$

Acharya ise, ABD'nin dünya düzeninin yerini neyin alacağı yönündeki soruların cevaplarının spekülatif olacağını ileri sürmüştür. Acharya uluslararası sistemdeki çok katmanlı yapının iki muhtemel senaryo sunduğunu bunların da küresel uyum modeli ile bölgesel dünya modeli olduğunu ifade etmiştir. $^{25} \mathrm{Bu}$ noktada, ABD'nin hegemonik düzeninin sona ermesi, Avrupa'nın uluslararası sistemde bölgesel bir güç olarak yerini almasına ve bu sebeple Transatlantik düzendeki kırılmanın derinleşmesine neden olmuştur.

24 John Mearsheimer, The Great Delusion: Liberal Dreams and International Realities (New Haven: Yale University Press, 2018), 239, (epublication)

25 Amitav Acharya, The End of American Order (Cambridge: Polity Press, 2014), 108. 
ABD'nin dış politika yapım sürecinde hegemonik liberal bir anlayıştan realist bir perspektife geçtiğini ileri sürmek mümkündür. Bu bağlamda, ABD'nin gelecek dönemde hem uluslararası düzeydeki gelişmeleri dikkate alan hem de iç faktörlerin belirleyiciliğinden etkilenen bir dış politika anlayışıyla uluslararası sistemde yer alacağı iddia edilebilir.

\section{Trump'ın Transatlantik Politikası}

Trump'ın başkan seçilmesi durumunda Avrupa'yı kendi sorunlarıyla baş başa bırakacağını ve ülkesinin iç problemlerine odaklanacağını belirtmesi ${ }^{26}$ zaman zaman sorunlu olmakla birlikte, İkinci Dünya Savaşı'ndan beri yakın şekilde süren ABD-Avrupa ilişkilerinde kırılma yaşanacağının sinyalini vermiştir. ${ }^{27}$ Başkan'ın adaylık döneminde sürekli kullandığ 1 "America First" (Önce Amerika) sloganı da Transatlantik ilişkiler bağlamında bir uzaklaşmayı işaret etmiş ve böylece, Trump, Avrupa' yla ilişkilerinde ülkesinin çıkarlarının birinci sırada olacağını vurgulamıştır. ${ }^{28} \mathrm{ABD}$-Avrupa ilişkilerinin karakterine bakıldığında Trump'ın tasarladığı ayrışmanın Birinci Dünya Savaşı'ndan önceki döneme benzediği göze çarpmaktadır.

Donald Trump'ın bu söylemleriyle seçimleri kazanıp ABD'nin 45. Başkanı seçilmesi Brüksel'de büyük bir tedirginlik yaratmıştır. Bu tedirginliği sadece Trump'ın sert açıklamaları meydana getirmemiştir. Avrupa'da önde gelen aşırı sağ siyasetçilerden Marine Le Pen, Nigel Farage ve Geert Wilders gibi isimler de Transatlantik ilişkilerdeki yakınlığa etki eden ekonomi gibi faktörlerin giderek zayıfladığını ve ilişkilerde bir kırılma yaşanacağını ileri sürmüştür. ${ }^{29}$ Nitekim Trump'ın dış politika anlayışı söz konusu tedirginliğin kaygılara dönüşmesine neden olmuştur. Bu bağlamda, Avrupa'nın kaygılarını artıran gelişmeleri Beyaz Saray'ın Rusya, Çin ve Ortadoğu ile ilişkilerinde muğlak politikalar izlemesi, BM ve NATO gibi uluslararası örgütlerin etkilerinde yaşanan erozyonlar, serbest ticaret anlaşmalarının revize edilmesi üzerinden göstermek mümkündür. Ayrıca Trump'ın 2015 yılında İran ile

26 Jeremy Shapiro ve Dina Pardijs, "The Transatlantic Meaning of Donald Trump: A US-EU Power Audit", European Council On Foreign Relations, 2017, 10.

27 Stephen M. Walt, "In Praise of a Transatlantic Divorce" Foreign Policy, May1s 30, 2017, https://foreignpolicy.com/2017/05/30/in-praise-of-a-transatlantic-divorce-trump-merkeleurope-nato/

28 Rachel Tausendfreund, "Transatlantic Views on President Trumps's First 100 Days in Office", Nisan 26, 2017, http://www.gmfus.org/blog/2017/04/26/transatlantic-viewspresident-trumps-first-100-days-office

29 Wickett, "Transatlantic Relations," 3. 
varılan nükleer anlaşmayı tartışmaya açması ve İsrail'in başkenti olarak Kudüs'ü tanıması söz konusu kaygıları derinleştirmiştir. ${ }^{30}$

Dahası Trump'ın politikaları, Rusya'nın gücünü artırması, Çin'in ekonomik yükselişi, Ortadoğu'daki çatışmaların derinleşmesi gibi sonuçlar ortaya çıkartmış ve Avrupa uzun zamandır müttefiki olan ABD'ye güvenemeyeceğini görmüştür. ${ }^{31} \mathrm{Bu}$ gelişmelere karşı, Avrupa Birliği'nin sembolik lideri Donald Tusk, ABD'nin en az Rusya ve Çin kadar Avrupa'yı da tehdit ettiğini belirmiştir. Hatta Tusk, ABD'nin bu belirsizliklerle dolu politikalarına karşı $27 \mathrm{AB}$ liderine mektup yazarak, ABD'deki değişimin Avrupa'y1 bir girdaba doğru sürüklediğini belirtmiştir. ${ }^{32}$ Dolayısıyla, Trump'ın politikaları Transatlantik ilişkilerde kırılma meydana getirmiş ve Batı dünyası kendi içinde $\mathrm{ABD}$ ve Avrupa olmak üzere ikiye ayrılmıştır.

Trump'ın Birleşmiş Milletler, AB, NATO ve çok taraflı ticaret düzenini sorgulaması da Avrupa'da endişeyle karşılanmıştır. ABD Başkanı, uluslararası sistemde önemli yer tutan BM ve NATO gibi yapıların ülkesine getirdiği ekonomik maliyetlere odaklanmıştır. Trump'ın uluslararası sistemin temellerini bu denli sorgulaması Cumhuriyetçi Parti içinde de karşıllk bulmuştur. Bu çerçevede Temsilciler Meclisi'nin Cumhuriyetçi üyesi Mike Rogers 2017 y1lında "Amerikan Egemenliğinin Restorasyonu Yasası" (American Sovereignty Restoration Act) isimli bir yasa tasarısını sunmuştur. Söz konusu yasa tasarısı kapsamında ABD'nin BM üyeliğini sonlandırılması yer almaktadır. ${ }^{33}$ Temsilciler Meclisi'nin dış ilişkiler komisyonuna gönderilen yasa tasarısı ile ilgili devam eden bir süreç bulunmamaktadır. Ancak bu gelişme Transatlantik düzendeki kırılmanın örneklerinden biri olarak görülmektedir. Ayrıca, ABD Başkanı, AB'nin ABD'yle rekabet edebilmek için var olduğunu ifade etmiştir. Trump'a göre $A B$, ekonomik güç kazanarak

30 Vincent L. Morelli ve Kristin Archick, “Transatlantic Relations in 2018”, CRS Insight, 2018, 1, Congressional Research Service.

31 Gideon Rachman, "Donald Trump's Unpredictability in Destabilising the World”, Financial Times, Mayıs 22, 2017, Erişim Tarihi: Kasım 21, 2018, https://www.ft.com/content/ b56c7c9c-3ecf-11e7-82b6-896b95f30f58

32 Andrew Rettman, "EU head calls Trump a "threat" to Europe", Ocak 31, 2017, Erişim Tarihi: Kasım 21, 2018, https://euobserver.com/foreign/136742. Ayrıca, Donald Tusk'ın 27 $\mathrm{AB}$ üyesine gönderdiği mektup için: "United We Stand, Divided We Fall": Letter by President Donald Tusk to the 27 EU Heads of State or Government on the Future of the EU Before the Malta Summit, European Council of the European Union, 2017.

33 H.R.193-American Sovereignty Restoration Act of 2017, 115th Congress (2017-2018), Erişim Tarihi: Aralık 28, 2018, https://www.congress.gov/bill/115th-congress/housebill/193 
ABD'nin gelirlerini düşürmektedir. Bu nedenle, Trump için ekonomik rekabette serbest ticaretin getirdiği kısıtlamalar sorun teşkil etmekte ve yeni düzenlemeler ile tarifeler getirilmesi gerekmektedir. ${ }^{34}$ Trump'ın bu görüşleri, Transatlantik ilişkileri kopma noktasına getirmiştir. Zira Avrupa'daki birçok lider, Trump'ın "Önce Amerika" söylemine dayalı dış politika anlayışından rahatsızlık duymuş ve ABD'nin ortaklığını sorgulamıştır. ${ }^{35}$

Transatlantik ilişkilerde yaşanan bir başka kırılma noktası da ABD öncülüğünde yapılan İran nükleer anlaşmasıdır. ABD’nin 44. Başkanı Obama, Nisan 2009'da Prag'da yaptığı konuşmada ${ }^{36}$ diyaloğa olan inancı ile ekonomik ve siyasi olarak İran'ın nükleer enerji ihtiyacının kuvvetli uluslararası denetim altında desteklenmesi görüşünü dile getirmişti. Söz konusu anlayış üzerine İran ve uluslararası toplum arasında Obama döneminde bir nükleer anlaşmaya varılmıştı.

Trump, selefi Obama'nın 2015 yılında Tahran ile yaptı̆̆ı nükleer anlaşmayı "tarihin en kötü anlaşması" olarak nitelemiş ve askıya almıştır. Ancak İran nükleer anlaşması, ABD ve Avrupa ülkelerinin ortak girişimiyle gerçekleşmiş ve Tahran'ın nükleer kapasiteye sahip silahlar geliştirmemesi amacını taşımıştır. ${ }^{37}$ Trump ise bu anlaşmanın İran'ın nükleer silah üretmesini engelleyemeyeceğini savunmuş ve Uluslararası Atom Enerjisi Kurumu (UAEK)'nun, İran'daki üslerde denetim yapması için uluslararası kamuoyundan izin talep etmiştir. Avrupa Birliği ve özellikle nükleer müzakerelerde önemli rol oynayan Almanya, Fransa ve İngiltere ise İran ile varılan anlaşmanın uluslararası sistemde güvenliği sağladığını ifade ederek, Trump'ın bu düşüncesine karşı bir duruş benimsemişlerdir. ${ }^{38} \mathrm{Bu}$ gelişmelerle birlikte, Atlantik'in iki yakasındaki ayrışma İran nükleer anlaşması üzerinden net şekilde görülmüştür. Nitekim Trump'ın İran nükleer anlaşmasından

34 Jules Johnston, "Donald Trump Says EU Exists to Compete With US", Politico, Temmuz 24, 2016, Erişim Tarihi: Kasım 29, 2018, https://www.politico.eu/article/donald-trumpsays-eu-exists-to-compete-with-us-brexit-nato-wto-nafa/

35 Vincent L. Morelli ve Kristin Archick, "Transatlantic Relations in 2018”, CRS Insight, 2018, 1, Congressional Research Service

36 Remarks By President Barack Obama In Prague As Delivered, Nisan 05, 2009, Erișim Tarihi: Mart 2, 2019, https://obamawhitehouse.archives.gov/the-press-office/remarkspresident-barack-obama-prague-delivered

37 Mark Landler, David E. Sanger ve Gardiner Harris, "Rewrite Iran Deal? Europeans Offer a Different Solution: A New Chapter", New York Times, Şubat 26, 2018, Erişim Tarihi: Aralık 2, 2018, https://www.nytimes.com/2018/02/26/us/politics/trump-europe-iran-deal.html

38 “AB'den Trump'a İran Çağrısı: Nükleer Anlaşmadan Çekilme”, $B B C$, Ocak 11,2018, Erişim Tarihi: Aralık 2, 2018, https://www.bbc.com/turkce/haberler-dunya-42648089 
çekilmesi ve İran'a yönelik yaptırım kararını tekrar yürürlüğe koyması Transatlantik düzenindeki kırılmayı derinleştirmiştir. Özellikle Trump yönetiminin Avrupa'nın ekonomik kaygılarını dikkate almadan tek taraflı bir anlayışla yaptırımları yeniden başlatması bahse konu kırılmanın başlıca sebebi olmuştur.

Transatlantik ilişkilerde yaşanan önemli bir diğer kırılma ise Trump'ın İsrail'in başkenti olarak Kudüs'ü tanıma kararı olmuştur. Avrupalı liderler, Beyaz Saray'ın bu kararını büyük bir hata olarak değerlendirmiş ve kararın Ortadoğu'ya barış getirmeyeceğini belirtmişlerdir. Trump'ın bu kararı, Ortadoğu ve Batı arasındaki bölünmenin fitilini ateşleyecek bir durum olarak gösterilmiş ve Batı'nın kendi içinde ikiye ayrıldığını göstermiştir. ABD'nin kararlarını takip etmeyeceğini söyleyen Avrupa, AB Dışişleri Bakanları aracılığıyla hem İsrail Başbakanı Netanyahu'yla hem de Filistin Devlet Başkanı Abbas ile görüşmeyi planlamıştır. Fakat bu görüşme girişimlerine rağmen Avrupa İsrail-Filistin çatışmasının mevcut durumu için adım atmamıştır. ${ }^{39}$

Trump, Transatlantik ilişkilerde yaşanabilecek farklı krizlere yönelik yapıcı bir vizyona da sahip değildir. ${ }^{40} \mathrm{Bu}$ bağlamda, Trump'ın Ulusal Güvenlik Strateji Belgesi de Avrupa'dan uzaklaşacağını göstermiştir. Özellikle iç güvenliğe odaklanan belge, uluslararası siyasette güç dengesini temel alarak politikalar geliştirileceğini ortaya koymuştur. ${ }^{41}$ Belge, Washington'un artık Avrupa'yı yekpare bir müttefik olarak görmediğini bunun yerine bölgedeki önemli güç odakları üzerinden politikalar sürdüreceğini göstermiş̧ir. Bu güç odakları, Birleşik Krallık ve Fransa olmuştur. Özellikle, Birleşik Krallık'ın AB'den ayrılması ve ABD ile olan köklü bağları Trump için politik nüfuz alanı açmıştır. Fransa ise Almanya ile Avrupa üzerinde yaşadığı güç mücadelesi nedeniyle ve NATO'daki önemli askeri varlığı dolayısıyla Trump'ın radarında olmuştur. Beyaz Saray böylece, Birleşik Krallık ve Fransa ile yakın ilişkiler kurarak Transatlantik politikasında yeni bir açı1ım meydana getirmeyi tasarlamıştır. Bu düşüncenin iyi bir yansımasını, 14 Nisan 2018 tarihinde Suriye'de Esed'e ait üs ve depoların kimyasal silah kullanımını caydırma amacıyla, ABD, Birleşik Krallık ve Fransa koalisyonu tarafından vurulması oluşturmuştur. ${ }^{42}$

39 Reinhard Bütikofer, "One Year of Trump: Looking at the Transatlantic Relationship", Reconnecting Europe, 2017.

40 Walt, "In Praise of a Transatlantic Divorce."

41 "National Security Strategy of the United States", The White House, 2017, 38.

42 "Joined by Allies, President Trump Takes Action to End Syria's Chemical Weapons Attacks", The White House, 2018. 
Tüm bu gelişmelerin Avrupa için kritik bir sınama oluşturduğu söylenebilir. Zira Avrupa'nın ABD'ye yoğun bir stratejik ve psikolojik bağımlılığı bulunmaktadır. Bu bağımlılığı ortaya koyan bir başka gelişme, Birleşik Krallık'ın Rusya ile yaşadığı diplomat krizidir. Londra, Birleşik Krallık'ta bulunan eski Rus ajanı Sergey Skripal ve kızı Yulia'ya suikast girişiminden dolayı Moskova'yı sorumlu tutmuş ve bu çerçevede 23 Rus diplomatı sınır dışı etmiştir. Peşi sıra, $A B D$ ve Avrupa ülkeleri de benzer yönde kararlar vermiştir. Toplamda 20 ülke 100 kadar Rus diplomatı sınır dışı etmiştir. ${ }^{43} \mathrm{Bu}$ durum, her ne kadar Birleşik Krallık ve Rusya arasındaki bir mesele gibi gözükse de Transatlantik boyunca yankı uyandırmıştır.

Yaşanan bu gelişmeler, Avrupa'nın Rusya'yı tehdit olarak görmesini körüklemiş, akıllara artan Rus tehdidine karşı NATO'nun nasıl bir politika izlemesi gerektiği sorusu gelmiştir. Trump ise NATO'daki ekonomik maliyeti öncelemektedir. $\mathrm{Bu}$ nedenle, Avrupa'nın ABD'nin olmadığı bir dünya siyasetine hazırlanması gerektiğini ve birlik içi bölünmelerin artacağını ifade etmek mümkündür. ${ }^{44}$

Bunlara ilaveten, Rusya'nın Azak Denizi'nde Ukrayna savaş gemilerine müdahale etmesi Rusya ve Ukrayna arasında uzun süredir devam eden çatışma sürecinde gerilimi yeniden arttırmıştır. Bu durum Avrupa'nın Rusya'ya karşı imkân ve kabiliyetleri kısıtlı bir aktör olduğunun önemli göstergelerinden birisidir. Nitekim Trump döneminde Avrupa'da çatışma riskinin artması NATO’nun geleceğinin de sorgulanması anlamına gelmiştir.

Yukarıdaki argümanları desteklercesine, 15-17 Şubat 2019 tarihlerinde gerçekleştirilen 55. Münih Güvenlik Konferansı'nda bu yılki gündem ABD'de Başkan Donald Trump'ın göreve gelmesi sonrasında dünyada değişen dengeler, büyük güçler arasındaki rekabetin yeni döneme etkileri ile Avrupa Birliği'nin ve transatlantik ilişkilerin durumu olmuştur. ${ }^{45}$ ABD'nin Avrupa için güvenilecek bir partner olup olmadığı ve nerede durduğu soruları "Büyük Bilmece: Parçaları Kim Toplayacak?" (The Great Puzzle: Who Will Pick Up the Pieces?) temasıyla toplanan Konferans’ta Batı'nın en çok

43 "Spy Poisoning: Russian Diplomats Expelled Across US and Europe”, BBC, Mart 262018, Erişim Tarihi: Aralık 3, 2018, https://www.bbc.com/news/world-us-canada-43545565 44 Shapiro ve Pardijs, "The Transatlantic Meaning," 12.

45 Munich Security Conference, "Munich Security Report 2019”, Erişim Tarihi: Mart 1, 2019 https://www.securityconference.de/en/publications/munich-security-report/munichsecurity-report-2019/ 
cevabını aradığı sorular olarak öne çıkmıştır. Merkel, uluslararası siyasi yapıların çöküşü konusunda uyarıda bulunurken, ABD Başkanı Donald Trump'a da atıfta bulunarak, "bu yapıyı parçalayamayız" mesajını vermiş ve uluslararası işbirliğinin genişletilmesi çağrısını yinelemiştir. Alman Şansölyesi, ABD ile Avrupa arasındaki farkları açıkça ortaya koymuş ve çok taraflı bir işbirliğini, kurala ve diplomasiye öncelik veren dış politika anlayışını savunmuştur. Konferans sonrasında yapılan yorumlarda genellikle Batı merkezli dünya düzeninin geleceğine ilişkin çıkarımlar yapılmıştır. The National Interest'de "Münih Konferansı Batı'nın gerilemekte olduğunu gösteriyor... Amerika ve Avrupa kendi yollarında gitmeye devam ediyor." yorumu yapilırken, ${ }^{46}$ Politico'da yapılan değerlendirmede ise konferans "Münih Güvensizlik Konferansı" olarak adlandırılmıştır. ${ }^{47}$ The Atlantic'deki Thomes Wright imzalı yorum ise "Transatlantik maskaralığının bittiği an" başlığı ile yayınlanmıştır. ${ }^{48}$ Nitekim Münih Konferansı ABD ve Avrupa'nın ayrışmasını ortaya koyan zirve olmuş, Merkel öncülügündeki Avrupa'nın bu ayrışmaya daha itidalli yaklaşması ve ittifakın parçalanmaması yönündeki çağrısına rağmen söz konusu ayrışmanın giderek derinleştiği endişesinin de bir göstergesi olmuştur.

\section{Trump ve NATO’nun Geleceği}

NATO'nun misyonu, SSCB'nin askeri olarak çevrelenmesiydi. SSCB dağıldıktan sonra kısa vadede yeni bir vizyon ortaya koymakta zorlanan İttifak, SSCB'nin yerini Rusya Federasyonu'nun aldığını uzun bir süre görmezden gelmiştir. Hatta 1990'l1 yillar boyunca ve 2000'lerin başında Rusya'nın Transatlantik düzende yer alabilecek bir ülke olduğu ileri sürülmüştür. 1997 'de NATO ve Rusya arasında ortak ilişkileri geliştirmeye dair bir anlaşma dahi yapılmıştır. ${ }^{49}$ Ancak, söz konusu öngörüler Rusya'nın

46 Jacob Heilbrun, "Munich Conference Exposes the Decline of the West", National Interest, Şubat 18, 2019, Erişim Tarihi: Mart 2, 2019, https://nationalinterest.org/feature/munichconference-exposes-decline-west-44922

47 Matthew Karnitschnig and David Herszenhorn, "Münich Insecurity Conference", Politico, Şubat 16, 2019, Erişim Tarihi: Mart 2, 2019, https://www.politico.eu/article/munichsecurity-conference-angela-merkel-mike-pence/

48 Thomas Wright, "The Moment the Transtlantic Charade Ended", The Atlantic, Subat 19, 2019, Erişim Tarihi: Mart 2, 2019, https://www.theatlantic.com/ideas/archive/2019/02/ mutual-distrust-2019-munich-security-conference/583015/

49 "Founding Act on Mutual Relations, Cooperation and Security between NATO and the Russian Federation signed in Paris, France”, Ekim 12, 2009, Erişim Tarihi: Aralık 6, 2018, https://www.nato.int/cps/en/natohq/official_texts_25468.htm 
Doğu Avrupa'da giderek daha sert politikalar uygulaması, Kırım'1 işgal ederek Ukrayna'nın toprak bütünlüğünü tehdit etmesi gibi gelişmelerle yerini güvenlik önlemlerine bırakmıştır. Bu bağlamda, Avrupa için SSCB'den sonra ortaya çıkan tehlike Rusya olmuştur. ${ }^{50} \mathrm{ABD}$ açısından baktığımızda ise Obama döneminde ABD reset (sıfırlama) politikası ile Rusya ile ilişkilerinde bir işbirliği dönemi başlatmak istemiştir. Müteakip dönemde Obama'nın Pivot to Asia (Asya Pivotu) ${ }^{*}$ politikasıyla ABD'nin odak noktası Çin başta olmak üzere Asya bölgesi olmuştur. Ancak $A B D$ ve Rusya arasında başta Ukrayna ve Suriye üzerine yaşanan ihtilaflar ABD'nin tehdit algısında Rusya'nın yerini korumasını sağlamıştır.

Trump ise Avrupa'nın karşı karşıya olduğu Rusya tehlikesini görmezden gelmiştir. Bu duruma işaret eden en önemli gelişme, NATO'nun 2017 yılında Brüksel'de gerçekleştirdiği zirve sırasında yaşanmıştır. Trump, zirvede yaptığı konuşmada NATO'nun ABD ve SSCB'ye dayalı iki kutuplu uluslararası sistemden kalma politikalardan kurtulması gerektiğini belirtmiştir. Trump ayrıca, Avrupalı müttefiklerine güvenlik endişesi duydukları konularda sadece ABD'ye güvenerek hareket etmemelerini, kendi savunma harcamalarını artırmalarını söylemiştir. ${ }^{51}$ Buna karşılık, Avrupa'nın NATO'dan beklentisi ise Rus yayılmacılığının engellenmesi olmuştur. Trump ise Rusya'nın Avrupa ve Ortadoğu'da gücünü artırmasına rağmen girişimde bulunmamış ve sadece ittifakın ekonomik maliyetlerine odaklanmıştır. Dolayısıyla, Trump'ın Avrupa'ya güvenliği NATO sağlayacaksa maliyetlerini sadece ABD'ye yüklemeyin mesajı vermesi, Transatlantik düzende yaşanan kırılmanın en belirgin göstergelerinden biridir. ${ }^{52}$ Nitekim ittifakın ekonomik yükü, 29 üye ülke tarafından karşılanmakta ve her bir üyenin GSMH nispetinin yüzde 2'sini NATO'nun savunma giderlerine ayırması öngörülmektedir. ${ }^{53}$ Trump, üye ülkeler arasında ciddi gelir farklılıkları bulunduğuna dikkat çekmiş ve belirlenen oranın adil olmadığını ifade etmiştir. Zira ABD ittifakın savunma harcamalarına en büyük katkııı

50 Steven Pifer, "The Growing Russian Military Threat in Europe”, Brookings, 2017.

Dışişleri Bakanı Hillary Clinton'ın 2011 yılında Foreign Policy dergisinde yazdığı "America's Pacific Century" isimli makalede "Pivot to Asia" politikasının temelleri ortaya koyulmuştur.

51 Milliyet, "Transatlantik İlișkilerde Yeni Dönem”, Erișim Tarihi: Aralık 26, 2018

52 Steven Pifer, "Is Trump Undoing Trans-Atlantic Relations?” Brookings, 2017.

53 Funding NATO, NATO, Erişim Tarihi: Aralık 24, 2018, https://www.nato.int/cps/en/natohq/ topics_67655.htm 
yapan ülkedir. ABD Başkanı bu nedenle, NATO'nun savunma giderlerinin yeniden düzenlenmesini istemektedir. ${ }^{54}$

Trump, 2018 yılında "Ulusal Savunma Strateji Belgesi"nde (National Defense Strategy) Avrupa'daki müttefiklerine çağrıda bulunarak, ittifakı güçlendirmek için savunma harcamalarını artırmalarının beklendiğini yeniden dile getirmiştir. ${ }^{55}$ Avrupa, bu beklentilere yönelik somut adım atmamış ve Transatlantik düzende yaşanan kırılma giderek derinleşmiştir.

Atlantik'in iki yakasının NATO'daki bu ayrışması, uluslararası sistemi de etkilemiştir. Özellikle, Trump'ın NATO'dan uzaklaşması ve Avrupa'nın savunma kaygıları yeni güvenlik birliklerinin meydana geleceğinin işareti olmuştur. Bu durumu, ABD Başkanı'nın 2017 yılının Aralık ayında yayınladığı Ulusal Güvenlik Strateji Belgesi desteklemiştir. Trump, bu belgede büyük çaplı ittifaklar yerine yakınlık tesis edebildiği yönetimleri esas alan politikalar ortaya koyacağını belirtmiştir. ${ }^{56} \mathrm{ABD}$ Başkanı, bu söylemiyle NATO'nun alternatifi olacak savunma ittifakları kurabileceğini göstermiştir.

Söz konusu gelişmeler, ABD'nin 2. Dünya Savaşı'ndan itibaren uygulamakta olduğu Transatlantik politikasından ciddi bir kopmayı işaret etmektedir. Trump dönemine kadar ABD'li politika yapıcıların, NATO'yu herhangi bir şekilde erozyona uğratacak ve Avrupa güvenliğini sağlamada NATO'yu ikincilleştirecek her türlü girişime karşı çekinceleri olmuştur. Bu nedenle 1980'lerin sonundan bu yana zaman zaman alevlenen ayrı bir Avrupa güvenlik kimliği oluşturulması çabalarına $\mathrm{ABD}$ her zaman mesafeli durmuş ve bu tür girişimlerin NATO'nun zayıflatacağını vurgulamıştır. ABD'nin, Avrupa'nın güçlü bir partner olmasını istemekle birlikte liderlikte kendisine ortak hale gelmesini istememesi söz konusu tavrın en önemli nedenidir. ${ }^{57}$

Trump'ın söz konusu söylemlerinin bir yansıması olarak Avrupa, SSCB'nin dağılmasından sonra da gündeme gelen kendi içinde bir güvenlik ittifakı kurmaya yönelmiştir. Özellikle, bölgenin güç odakları Almanya ve Fransa öncülüğünde askeri bir ittifakın oluşturulması fikri kuvvet kazanmıştır. $\mathrm{Bu}$ anlamda, NATO'ya alternatif olabilecek Avrupa Birliği merkez ordusu

54 Michael Mandelbaum, "Pay Up, Europe What Trump Gets Right About NATO," Foreign Affairs, Eylül/Ekim 2017.

55 National Defense Strategy of the United States of America, Department of Defense, 2018, 9.

56 National Security Strategy of the United States, The White House, 2017, 38.

57 Smith, "The USA and the EU," 240-242. 
tartışmaları yapılmış ve uluslararası düzende uzun dönemdir hakim olan Transatlantik güvenlik paradigması değişmeye başlamıştır.

\section{NATO'nun Alternatifi AB Merkez Ordusu}

SSCB'nin dă̆ılmasının ardından uluslararası sistemdeki dengeler değişmiş, hakim güvenlik paradigması dönüşüm geçirmiştir. Bu dönemde, NATO'nun geleceği üzerine tartışmalar yapılmış ${ }^{58}$ ve Avrupa güvenliğini sağlamak için yeni bir ordu kurmaya yönelmiştir. Böylece Avrupa, 1990'ların başlangıcında ortak güvenlik ve savunma politikası* oluşturmaya çalışmıştır. 1992 yılında, AB üyeleri tarafindan imzalanan Maastricht anlaşmasıyla, Avrupa'yı merkeze alan ortak güvenlik ve savunma politikalarının belirlenmesi adına ciddi bir girişim yapılmıştır. ${ }^{59}$ Ancak NATO, Soğuk Savaş sonrasında genel konseptinde değişim geçirmiş, AB'yi de yakından ilgilendiren yeni tehditler, terörizm, mülteci akınları ve etnik temelli ayrımcılık gibi sorunlara eğilmiştir. ${ }^{60} \mathrm{Bu}$ nedenle, AB'nin güvenliğinin sağlanmasında NATO birinci sıradaki yerini korumuş ve yeni bir ordu kurulmamıştır. Trump dönemine kadar devam eden bu görüş, Washington ve Brüksel arasında NATO üzerinden ortaya çıkan fikir ayrılığıyla yeniden alevlenmiştir. Bu bağlamda, AB üye ülkeleri, “AB Dış Politikası ve Güvenlik Alanına Dair Küresel Strateji” (EU Global Strategy for Foreign and Security Policy) vizyonunu ortaya koyarak, üye ülkeler arasında yakın işbirliğinin tesis edilmesi ve savunma kapasitelerinin artırılmasını öngörmüştür. ${ }^{61} \mathrm{Bu}$ vizyon dahilinde, "Kalıcı Yapılandırılmış İşbirliği Savunma Anlaşması" (Permanent Structured Cooperation, PESCO) Avrupa Birliği üyelerinin gündemine girmiştir.

PESCO, 25 Avrupa Birliği üyesini bir araya getirerek savunma ittifakı ve ordu kurmayı hedeflemektedir. Bu girişim, hem Birliğin güvenlik kaygılarının önüne geçilmesi hem de gerektiğinde bağımsız askeri operasyonların

58 A Short History of NATO, NATO, 2018, Erişim Tarihi: Aralık 26, 2018, https://www.nato.int/cps/ie/natohq/declassified_139339.htm

*Bu konudaki tartışmalar için; Batı Avrupa Birliği ve Batı Almanya'nın silahlandırılması çerçevesinde ordunun NATO'yla bütünleşmesi ve Birleşik Avrupa Görev Gücü çalışmalarına bakılabilir.

59 "Treaty on European Union, Maastricht," Office for Official Publications of the European Communities, 1992, 4.

60 The Daedalus European Security: The Interactions of NATO, EU, WEU, NATO, Erişim Tarihi: Aralık 18, 2018, https://www.nato.int/acad/fellow/98-00/hatjiadoniu.pdf

61 Permanent Structured Cooperation-PESCO, European Union External Action, 2018, 1. 
yapılabilmesinin önünü açmayı hedeflemektedir. ${ }^{62} \mathrm{ABD}$ de benzer şekilde NATO'nun bütçesine katkı yapan en büyük ortak olarak, Avrupa'nın kendisini savunması için girişimde bulunmasını istemiştir. Fakat Beyaz Saray'ın bu düşüncesi kıtanın savunmasında önemli rol oynayan NATO'nun geleceğine dair soru işaretleri meydana getirmiştir. Bu soru işaretlerinden en dikkat çekeni, NATO ve PESCO arasında koordinasyonun nasıl sağlanacağı üzerinedir. Zira PESCO'yu oluşturan devletler ile NATO üyesi devletlerin aynı rolü üstelenmesinin bir sorun teşkil ettiğini ifade etmek mümkündür. ${ }^{63}$ Ancak, ABD Hava Kuvvetleri Generali ve NATO müttefik Hava Gücü Komutanı Tod Wolters, NATO ve PESCO arasındaki koordinasyona vurgu yaparak, askeri unsurların ortak paydalar oluşturmasına ve koordinasyonu geliştirmesine yönelik olumlu yaklaşım sergilemiştir. Wolters, iki ittifak arasında azami ölçüde şeffaf bir ilişki kurmayı hedeflediklerini sözlerine eklemiştir. Ayrıca Almanya, NATO'nun kıtadaki savunma rolünün devam edeceğini, PESCO'nun ise insani yardım odaklı operasyonlarda rol alacağını belirtmiştir. ${ }^{64}$

PESCO'ya yönelik bir diğer soru işareti, AB merkez ordusunun uluslararası sistemdeki güvenlik paradigmasını etkileyeceğine yöneliktir. ${ }^{65}$ $\mathrm{Bu}$ savı doğrulayacak şekilde, PESCO, AB üyeleri tarafından belirlenen tehditlere karşı hareket edecek ${ }^{66}$ ve bu kapsamda kıta dışında kalan uluslararası terörizm gibi sorunlara karşı adım atmak zorlaşacaktır. Nitekim Avrupa'nın giderek kendi güvenliğini sağlamaya yönelmesi ve NATO'nun ünlü 5. Maddesinin -taraflardan herhangi birine saldırı durumunda ittifakın tamamına saldırı yapılmış sayılacağının kabul edilmesi- ${ }^{67}$ birbiriyle çelişkili içerikler olduğu savı gündeme gelmektedir. Ancak, transatlantik ilişkilerin geleceğini şekillendirecek PESCO, Avrupa'nın iç güvenliğinde öncelikli

62 Permanent Structured Cooperation-PESCO, European Union External Action, 2018, 1.

63 Deutsche Welle, “Beş Soruda AB'nin Ortak Savunma Anlaşması”, Erişim Tarihi: Aralık 13, 2018, https://www.dw.com/tr/be\%C5\%9F-soruda-abnin-ortak-savunma-anla\%C5\%9Fmas $\% \mathrm{C} 4 \% \mathrm{~B} 1 / \mathrm{a}-41355539$

64 Reuters, "EU to Sign Joint Defense Pact in Show of Post-Brexit Unity", Kasim 8, 2017, Erişim Tarihi: Aralık 13, 2018, https://www.reuters.com/article/us-eu-defence/eu-to-signjoint-defense-pact-in-show-of-post-brexit-unity-idUSKBN1D81CT

65 Annegret Bendiek, "A Paradigm Shift in the EU's Common Foreign and Security Policy: From Transformation to Resilience", Stiftung Wissenschaft und Politik German Institute for International and Security Affairs, 2017, 5-6, SWP Research Paper.

66 Bendiek, "A Paradigm Shift," 14.

67 Collective Defence-Article 5, NATO, 2017, Erişim Tarihi: Aralık 15, 2018, https://www.nato.int/cps/en/natohq/topics_110496.htm 
sorumlu olacak ve bir anlamda 5. Madde işlevsiz kalacaktır. Zira NATO’yu harekete geçiren birlik üyeleridir ve bu üyeler kendilerine ait farklı bir savunma ittifakına girişerek ne NATO'yu savunmaya çağıracak ne de NATO ülkelerinin taleplerine cevap vereceklerdir.

Tüm bu soru işaretleriyle birlikte, Avrupa'nın içerisinde PESCO'ya karş1 muhalif sesler yükselmiştir. $\mathrm{Bu}$ bağlamda, Avrupa'daki savunma harcamalarının özensiz şekilde planlandığı, vergilerini ödeyen vatandaşların paralarının boşa gideceği gibi argümanlar ileri sürülmüştür. ${ }^{68}$ Fakat Avrupa'nın NATO'nun olmadığı bir uluslararası sistemde kendisini savunması gerekmektedir. Bu çerçevede, birlik üyelerinin her birinin kendi ordusunu kurması ya da güçlendirmesi ihtimal dahilindeyken AB'nin entegrasyon niteliği gereği kollektif savunma daha tercih edilebilir bir seçenek olarak gözükmektedir.

Ayrıca bu tartışmalara ek olarak, Almanya'nın kıtada liderliği ele geçirerek PESCO'yu yönlendirme ihtimali bulunmaktadır. Şüphesiz Fransa'yı rahatsız eden bu durum, Birleşik Krallık'ın birlikten çıkma kararından sonra belirgin hale gelmiştir. Bu çerçevede Brexit sonrası Avrupa'da bir güç parçalanması yaşanmış ve Birleşik Krallık, Fransa ve Almanya arasındaki çekişme bu durumun yansıması olmuştur.

\section{VI. “Brexit”" Tartışması Sonrasında Avrupa'daki Güç Parçalanması}

Trump, Birleşik Krallık'ın AB'den çıkış sürecine destek vermiş ve bu söylemleri Londra'da olumlu karşılanmıştır. Özellikle, Trump'ın Obama'nın aksine ticaret alanında Birleşik Krallık'a ayrıcalıklı davranacağını ifade etmesi Brexit sürecinde etkili olmuştur. Böylelikle Beyaz Saray'ın Londra ile özel ticari ilişkilerini artıracağı beklentisi oluşmuştur. Söz konusu gelişmelerle birlikte Birleşik Krallık ise Avrupa'dan giderek uzaklaşmıştır.

Brexit tartışması, güvenlik ve savunma alanlarında Avrupalıların siyasi gücünü azaltmıştır. Ancak savunma ve güvenliğin $\mathrm{AB}$ 'nin temel meseleleri arasında olmaması Birleşik Krallık'ın birlikten ayrılma tartışmasında olumlu bir etken olmuştur. ${ }^{69}$ Avrupa'da Brexit'ten sonra, güvenlik ve çıkarlarını korumaya dair ciddi bir endişe meydana gelmiştir. Özellikle, küresel

68 Bütikofer, "One Year of Trump: Looking at the Transatlantic Relationship".

69 Claudia Major ve Christian Mölling, "Brexit, Security and Defence: A Political Problem, Not a Military One", Swedish Institute of International Affairs, 2017. 
siyasetteki gelişmeler göz önünde bulundurulduğunda, artan popülizm ve radikal sağ görüşlerle birlikte, ${ }^{70}$ ortak bir güvenlik paradigmasından bahsetme imkanı giderek daralmaktadır. Bu süreçte, Almanya bölgedeki ekonomik ve politik gücünü giderek arttırarak $A B$ 'nin liderliğine doğru yol almıştır. Ukrayna krizinde Fransa'yı yanına alarak Rusya'yı dengeleyen Almanya AB çerçevesinde İran, Suriye ve Irak'taki mücadelelerde kriz yöneticisi pozisyonuna gelmiştir. ${ }^{71}$

Ayrıca, Avrupa Birliği içerisinde "stratejik özerklik" kavramının yeri bulunmaktadır. Bu bağlamda, 2013 Avrupa Küresel Strateji Raporu bölgesel stratejik özerklik kavramını önermiş, 2016 yılında AB'nin Dış İlişkiler ve Güvenlikten Sorumlu Yüksek Temsilcisi Federica Mogherini tarafından Avrupa Birliği Küresel Stratejisinde özerkliğin önemine değinilmiştir. ${ }^{72}$

ABD, Avrupa'daki bazı ülkelerin özerk hareket etmesi ve güvenliği sağlamasına dair tartışmalarda her ne kadar çekinceleri olsa da destekleyici bir tutum sergilemiştir. Bu tutumunu Trump döneminde daha net ortaya koymuştur. $\mathrm{AB}$ içerisindeki aktörlerin müstakil politikalar geliştirmesinin arka planında Fransa, Almanya ve Birleşik Krallık arasındaki etkileşim ve Trump'ın Avrupa'daki güç parçalanmasına etkisi önemli yer tutmaktadır. Birleşik Krallık'ın AB'den ayrılma kararından sonra Fransa AB'de Almanya'ya karşı tek denge unsuru olarak kalmış ve merkezi gücünü korumayı istemiştir. Ancak, AB'deki orta büyüklüğe sahip Hırvatistan ve Polonya gibi ülkeler, Birleşik Krallık'ın AB'den ayrılmasının ardından oluşan boşluktan endişe duymuşlardır. Bu durum özellikle istihbarat paylaşımı ve terörle mücadele konularında kendisini göstermiştir. ${ }^{73}$

$\mathrm{Bu}$ gelişmelerin yanı sıra, 2008 yılında yaşanan ekonomik kriz Avrupa içindeki mücadelenin açık bir şekilde ortaya çıkmasına neden olmuştur. Özellikle, bölgedeki büyük devletlerin stratejik çıkarları arasındaki farklar giderek belirli kutupların oluşmasına neden olmuştur. Böylece Avrupa'da Almanya, Fransa ve Birleşik Krallık'ın öne çıtı̆ğ ${ }^{74}$ bir güç mücadelesi

70 Wickett, "Transatlantic Relations Converging or Diverging?"

71 Stefan Fröhlich, "Germany Cannot Replace the US, But Europe Can Live with Trump", Center for Transatlantic Relations, 2017.

72 Björn Fägersten, “Transatlantic Turbulence-Implications for European Security”, Swedish Institute of International Affairs.

73 Major ve Mölling, "Brexit, Security qnd Defence: A Political Problem, Not a Military One."

74 Kyriakos N. Demetriou, The European Union in Crisis, (New York: Springer Publishing, 2015), 15. 
meydana gelmiştir. Özellikle, finansal krizi iç dinamikleriyle yararına döndüren Almanya, ekonomik gücü sayesinde $A B$ 'de yerleşik egemen bir siyasi rol elde etmiştir. ${ }^{75}$ Almanya'nın Avrupa'da liderliğe soyunması diğer ülkeler tarafından "politik dikte" olarak algılanmıştır. Nitekim diğer Avrupa ülkeleri Almanya'nın ekonomik gücü ve küresel finans krizini müteakip anılan ekonomik gücünü kullanmasından rahatsız olmuştur. ${ }^{76}$

ABD ile Almanya arasındaki ilişki ise İkinci Dünya Savaşı'ndan sonraki dönemde iç içe geçmiş ve bu durum ekonomik anlamda karşılıklı bağımlılığı artırmıştır. Üstelik 1990 yılında Almanya'nın birleşmesi sürecinde ABD'nin katkıları ve Washington'a duyulan güven, ikili ilişkilerin ne denli yakın olduğunu göstermektedir. Ancak, Trump'ın Almanya'ya karşı politikaları ve yine ekonomik veriler üzerinden gelişen tepkileri ikili ilişkilerin arasını açmış ve belki de Berlin ilk defa $\mathrm{ABD}$ stratejilerinin gerekliliğini tartışmaya başlamıştır. ${ }^{77}$ Ayrıca Trump yönetime geldikten sonra Paris İklim Anlaşmasını iptal etmiş, İran nükleer programına karşı varılan mutabakatı görmezden gelmiş, Almanya'nın ticaret fazlasını eleştirmiş ve NATO'ya katkılarını yetersiz bulmuştur. Tüm bu gelişmeler ise Almanya'yı rahatsız etmiştir. $^{78}$

Üstelik ABD'nin Avrupa'da kolektif güvenliğe dayanan bir yapısının bulunması Almanya'nın güçlü yükselişinde önemli bir frenleyici unsur teşkil etmiştir. Öyle ki, Washington Almanya'nın güvenlik bağlamında kendisinin belirlediği bir eksen dahilinde hareket etmesini sağlayarak, yeni bir vizyon ile bölge liderliğine soyunmasının önüne geçmiştir. Nitekim ABD Almanya'nın kendi çıkarlarıyla çelişen kararlar almasını bu güvenlik yapısı üzerinden engellemeye çalışmıştır. ${ }^{79} \mathrm{Bu}$ çerçevede Almanya-ABD arasındaki ilişkiler Trump'in dünya liderliğini kaybedeceğine dair görüşlerin Avrupa'da geniş yankı bulmasına neden olmuştur. Böylece Beyaz Saray'ın yerini Berlin doldurabilir mi sorusu gündeme gelmiştir. ${ }^{80}$ Almanya'daki siyasi aktörlerin

75 Demetriou, The European Union, 24.

76 Demetriou, The European Union, 27.

77 Constanze Stelzenmüller, "Normal is Over", Brookings-Robert Bosch Foundation Transatlantic Initiative, 2018, 5-6, Report.

78 Reuters Staff, "Germans see Trump as Bigger Problem than North Korea or Russia", Aralık 4 2017, Erişim Tarihi: Aralık 14, 2018, https://www.reuters.com/article/us-usa-germanysurvey/germans-see-trump-as-bigger-problem-than-north-korea-or-russiaidUSKBN1DZ0GY

79 Kielinger ve Otte, "Germany: The Pressured Power", Foreign Policy, no.91 (1993): 60. 80 Fröhlich, "Germany Cannot Replace the US, But Europe Can Live with Trump." 
çoğu, Washington'un Berlin'e uzun yıllardır verdiği desteğin farkındadır. Ayrıca, ABD'nin liberal uluslararası düzeni desteklemede hayati önem arz ettiğini görmektedirler. $\mathrm{Bu}$ nedenle, söz konusu düzenin bir alternatifinin olmadığı iddia edilmektedir. ${ }^{81}$

Bu noktada, Trump'ın Almanya'ya karşı tutumu ABD'nin kendi eliyle Batı sisteminin bir parçası haline getirdiği Almanya'yı izolasyona doğru sürüklediğini göstermektedir. Almanya için Avrupa'nın merkezinde diğer ülkelerden kopuk ve $\mathrm{ABD}$ ile çatışan bir görüntü sergilemek sorun oluşturmaktadır. ${ }^{82}$ Buna binaen, Merkel 2017 yılı Mayıs ayında yaptığı bir konuşmada Avrupa'nın ABD ve Birleşik Krallık'a güvenemeyeceğini dile getirmiştir. Avrupalılar olarak kaderlerini kendilerinin belirleyeceğine vurgu yapan Alman Şansölyesi'nin sadece Almanya üzerinden yola çıkmayarak tüm Avrupa'yı kast etmesi dikkat çekicidir. ${ }^{83}$ Nitekim Almanya Dışişleri Bakanı Heiko Maas yazdığı bir makalede Trump'ın dış politikasına yönelik yeni bir strateji ortaya koymuştur. Söz konusu yazıda Maas, Trump'ın diş politikasının Avrupa Birliği'ne yönelik etkisini ortaya koyarken Avrupa'nın ABD'ye karş1 ağırlık oluşturacak bir aktör olarak hareket etmesi gerektiğini belirtmiştir. ${ }^{84}$

Maas'ın makalesinde çerçevesi çizilen bu strateji ancak AB'nin bağımsız bir savunma ve dış politika geliştirecek imkân ve kabiliyetlere sahip olmasıyla mümkün olacaktır. Bu çerçevede Almanya'nın küresel sistemde ABD'nin yerini doldurmasından bahsetmek mümkün olmasa da Avrupa'da önemli ölçüde ABD'nin gücünü ele geçirmeye çalışacağını iddia etmek mümkündür. Özellikle Trump Avrupa'yı ötekileştirmeye devam ettikçe kıta içerisinde Almanya'nın önde geldiği bir liderlik yarışının meydana geldiği dikkat çekmektedir. Bu bağlamda ABD-Avrupa ilişkileri siyasi düzlemde ciddi bir kırılma yaşarken ABD’nin söz konusu ilişkilerin ekonomik boyutuna daha farklı bir yaklaşıma sahip olduğu görülmektedir.

81 Erik Brattberg ve Viola Meyerweissflog, “The Trump Effect on Germany's Election and Transatlantic Ties", Carnegie, 2017.

82 Gideon Rachman, "Multilateralism In One Country: The Isolation of Merkel's Germany", Paper Series, Transatlantic Academy, 2017.

83 Frum, "Trump's Trip Was a Catastrophe for U.S.-Europe Relations."

84 Fabian von der Mark, "Germany's New Strategy to Deal with Donald Trump", Ağustos 24 2018, Erişim Tarihi: Aralık 18, 2018, https://www.dw.com/en/germanys-new-strategy-todeal-with-donald-trump/a-45217235 


\section{Transatlantik Ekonomisinin Geleceği}

Transatlantik ekonomisinin y1llk 5,5 trilyonluk bir hacmi bulunmaktadır. Aynı zamanda, Atlantik'in her iki yakasında karşı1ıklı 15 milyon işçi çalışmaktadır. Söz konusu özellikleri nedeniyle transatlantik ekonomisi dünyanın en büyük ve en zengin piyasasıdır. ${ }^{85} \mathrm{Bu}$ durum, $\mathrm{ABD}$ ve Avrupa arasında yakın bir ticaret ilişkisi meydana getirmiştir.

ABD Başkan Yardımcısı Michael Pence, 20 Şubat 2017 tarihinde Brüksel'deki AB kurumlarına bir ziyarette bulunmuştur. Bu ziyaretle birlikte, transatlantik bağlarının ekonomi üzerinden geliştirilmesine dikkat çekilmiştir. Nitekim Trump dönemiyle birlikte Transatlantik Ticaret ve Yatırım Ortaklığı (TTIP) müzakerelerinin yeniden başlatılması ve Transatlantik Ekonomik Konseyi (TEC)'in kuvvetlendirilmesi fikri öne çıkmıştır. ${ }^{86}$ Ancak Trump'ın bu yaklaşımı ABD'nin çıkarlarını temel almaktadır. 2017 yılı içerisinde ABD hükümeti verilerine göre $\mathrm{AB}$ ile $\mathrm{ABD}$ arasındaki ticaret hacmi gelişme göstermiştir. Örneğin 2017 yılının sonuna yaklaşırken yüzde 2,7 artan ticaret hacmi 526 milyar ABD Doları'na ulaşmıştır. Bu artışta Almanya'nın payı da yüzde 2,8 artmış ve 126 milyar ABD Doları'na yükselmiştir. ${ }^{87}$ Söz konusu durum Trump'ın politikalarıla yakından ilgilidir. Öyle ki “ekonomik üstünlük" temelli bir yaklaşım sergileyen ABD Başkanı bu gücünü artırmak için dış politika ve güvenlik konularında Avrupa'dan uzaklaşırken ekonomik alanda üstünlük kurmak istemiştir sürdürmüştür. Bu yönüyle Trump için öncelik ABD ekonomisi olmuş ve herhangi bir ekonomik düşüş yaşanmaması için gayret göstermiştir.

Ayrıca Transatlantikteki ekonomik düzen için kritik bir önem taşıyan Transatlantik Ekonomik Konseyi (TEC)'in yeniden canlandırılması fikri, Çin'in dünya ekonomisindeki yükselişine karşı bir dengeleme aracı olma ihtimalini de taşımaktadır. Trump'ın ekonomi politikalarında stratejik bir vizyon oluşturması gerekliliği Çin'in yükselişinin önemiyle eşdeğerdir. Ancak, ABD ve Avrupa taraflarının bu girişimler için ortak bir paydayı

85 Daniel S. Hamilton ve Joseph P. Quinlan, "The Transatlantic Economy”, Center For Transatlantic Relations, 2018, Report.

86 Peter Chase, "Rebuilding Strategy into the Transatlantic Economic Relationship", The German Marshall Fund of the United States, 2017.

87 Emily Schultheis and Matthew Karnitschnig, "On Transatlantic Trade, Trump is All Bluster, No Bite-So Far”, Kasım 15 2017, Erişim Tarihi: Kasım 24, 2018, https://www.politico.eu/ article/donald-trump-transatlantic-trade-bluster-no-bite-so-far/ 
oluşturduğunu söylemek mümkün değildir. ${ }^{88}$ Öyle ki, Trump, ekonomik bağımlılık üzerinden Avrupa'yı tehdit etmiştir. Bunların en dikkat çekeni, çelik ve alüminyum ithalatına tek taraflı vergi uygulaması getirmesi ve özellikle Almanya için kritik önem arz eden otomobil ithalatına ek vergilerin koyulacağını ifade etmesidir. Trump, Almanya'daki otomobil üreticilerine “ABD'ye gelen her bir araba için” yüzde 35'lik bir vergi artış1 getirmekle meydan okumuştur. ${ }^{89}$ Böylece Trump bir yandan ticari olarak Avrupa'yla ilişkilerinde lehinde sonuçlar almaya devam etmiştir. ABD Başkanı öte yandan Avrupa'ya karşı ekonomik silahlarını (ek vergiler vb) kullanarak siyasi yarar kazanmayı da ummuştur. Keza, bu gelişmelerle birlikte Trump, Transatlantik ekonomi birliğinin 9 Haziran 2018 tarihinde düzenlenen G7 zirvesinde kriz yaratmış ve serbest piyasanın öngörülerini sarsmaya devam etmiştir. ${ }^{90}$

\section{Sonuç}

Trump'ın dış politikası Transatlantik ilişkileri derinlemesine sarsmış ve mevcut düzende ciddi bir kırılma meydana getirmiştir. Söz konusu kırılmanın kalıcı bir hale dönüşme potansiyeli taşıdığ 1 ve uzun vadeli sonuçlara sebebiyet verebileceği görülmüştür. Atlantik düzeninde gerçekleşen bu kırılmanın sonuçlarını siyasi, ekonomik ve güvenlik boyutları ile ortaya koymak mümkün hale gelmiştir.

İlk olarak, ABD Başkanı, geleneksel müttefiki olan Avrupa'yı siyaseten ötekileştirmiş ve ekonomik politikalar üzerinden köşeye sıkıştırmıştır. Beyaz Saray, Avrupa'nın önemli güçleri olan Birleşik Krallık, Fransa ve Almanya arasındaki güç dengesine oynayarak $\mathrm{AB}$ içindeki parçalanma sürecini hızlandırmıştır. Ayrıca geçmiş dönemlerde bir işbirliği ve ortaklık alanı olarak görülen uluslararası ticaretin Trump döneminde ABD ve Avrupa arasında bir çatışma alanına evrildiği belirlenmiştir. Atlantik düzeni içerisindeki ticaret savaşı hem Transatlantik ilişkilerde ciddi bir çatlak yaratmış hem de tüm dünya ticareti için önemli bir soruna dönüşmüştür. Bunlara ilaveten Trump,

88 Chase, "Rebuilding Strategy into the Transatlantic Economic Relationship."

89 Brent D. Griffiths, "Trump Threatens EU with Tax on Car Imports", Politico, Mart 3, 2018 , Erişim Tarihi: Aralık 16, 2018, https://www.politico.eu/article/trump-threatens-eu-with-taxon-car-imports/

90 David Herszenhorn, “Trump dismisses Europe's trade pitch”, Politico, Eylül 6 2018, Erişim Tarihi: Kasım 7, 2018, https://www.politico.eu/article/us-president-donald-trumpdismisses-europes-trade-pitch/ 
NATO'yu zayıflatacak söylemlerde bulunmuş ve bu doğrultuda politikalar geliştirmiştir. Oysaki Transatlantik düzenin devamlılığında en önemli etkenlerden bir diğeri savunma ve güvenlik alanında işbirliği olmuş ve NATO Atlantik'in iki yakası arasındaki ilişkilerde lokomotif görevi görmüştür. Ancak Başkan'ın söz konusu tavrı nedeniyle Avrupa'da AB Merkez Ordusu kurulması tartışmaları alevlenmiş, NATO'nun alternatifi olabilecek ve Avrupa güvenliğinde NATO'yu zayıflatacak bölgesel savunma ittifaklarının kurulma ihtimali artmıştır.

Transatlantik düzendeki kırılma Batı'nın küresel sorunlara ilişkin ortak çözümler bulma kabiliyetini de sekteye uğratmış ekonomiden, savunmaya birçok farklı alanda Atlantik'in iki yakasının başka tercihlerde bulunmasına neden olmuştur. Yakın zamanda gerçekleştirilen Münih Konferansı da Transatlantik ittifakının ciddi biçimde çatladığını göstermiştir. Özellikle Merkel'in Atlantik düzeninin parçalanmamasına ilişkin yaptığ itidal çağrısı ve Avrupa'nın konuya ilişkin bekle-gör politikasına rağmen, konferans sonrası söz konu ayrışmanın kalıcı olabileceği yorumları öne çıkmıştır.

Mevcut durum ve Beyaz Saray'ın dile getirilen politikaları ABD'nin güçlenmesine değil aksine yalnızlaşmasına neden olmuştur. Bu çerçevede ABD'nin giderek daha da yalnızlaşacağını ve müttefikler arasında Transatlantik'te yaşanan söz konusu kırılmanın sadece Avrupa'yla sınırlı kalmayacağını söylemek olası hale gelmiştir. Dolayısıyla Ortadoğu başta olmak üzere bölgesel güçlerin nüfuzlarını giderek genişletmesi ve Avrasya'daki ülkelerin gücünü artırması kuvvetle muhtemel görülmüştür. Avrasya'da Çin öncülügünde yeni bir güç merkezinin yükselmesi de bu durumun en belirgin örneği olarak öne çıkmıştır. 


\section{Kaynakça}

AB'den Trump'a İan çă̆risl: Nükleer anlaşmadan çekilme. 11 Ocak 2018. https://www.bbc.com/turkce/haberler-dunya-42648089.

Acharya, Amitav. The End of American World Order. Cambridge: Polity Press, 2014.

Bendiek, Annegret. A Paradigm Shift in the EU's Common Foreign and Security Policy: From Transformation to Resilience. Berlin: Stiftung Wissenschaft und Politik, 2017.

Beş soruda AB'nin ortak savunma anlaşması. 13 Kasım 2017. https://www.dw.com/tr/ be $\%$ C5\%9F-soruda-abnin-ortak-savunma-anla\%C5\%9Fmas\%C4\%B1/a-41355539.

Blumer-Thomas, Victor. Empire in Retreat: The Past, Present and Future of the United States. New Haven: Yale University Press, 2018.

Brattberg, Erik, ve Viola Meyerweissflog. «The Trump Effect on Germany’s Election and Transatlantic Ties.» Carnegie Endowment for International Peace. 31 Ağustos 2017. https://carnegieendowment.org/2017/08/31/trump-effect-ongermany-s-election-and-transatlantic-ties-pub-72972.

Bütikofer, Reinhard. One Year of Trump: Looking at the Transatlantic Relationship. 18 Aralık 2017. http://reconnecting-europe.boellblog.org/2017/12/18/one-yearof-trump-looking-at-the-transatlantic-relationship/.

Chase, Peter. «Rebuilding Strategy into the Transatlantic Economic Relationship.» The German Marshall Fund of the United States. 20 Şubat 2017. http://www.gmfus.org/blog/2017/02/20/rebuilding-strategy-transatlanticeconomic-relationship.

EU to sign joint defense pact in show of post-Brexit unity. 8 Kasim 2017. https://www.reuters.com/article/us-eu-defence/eu-to-sign-joint-defense-pact-inshow-of-post-brexit-unity-idUSKBN1D81CT.

Fägersten, Björn. Transatlantic turbulence - implications for European security. Stockholm: The Swedish Institute of International Affairs, 2017.

«Founding Act on Mutual Relations, Cooperation and Security between NATO and the Russian Federation signed in Paris, France.» NATO. 12 Ekim 2009. https://www.nato.int/cps/en/natohq/official_texts_25468.htm.

Fröhlich, Stefan. «Germany Cannot Replace the US, But Europe Can Live with Trump.» Center for Transatlantic Relations. Şubat 2017. https://archive.transatlanticrelations.org/publication/germany-cannot-replaceus-europe-can-live-trump-stefan-frohlich/. 
Frum, David. «Trump's Trip Was a Catastrophe for U.S.-Europe Relations.» The Atlantic, 2017.

Germans see Trump as bigger problem than North Korea or Russia. 5 Aralık 2017. https://www.reuters.com/article/us-usa-germany-survey/germans-see-trump-asbigger-problem-than-north-korea-or-russia-idUSKBN1DZ0GY.

Griffiths, Brent. «Trump threatens EU with tax on car imports, slams 'very stupid' trade deals.» Politico. 3 Mart 2018. https://www.politico.com/story/2018/03/03/ trump-trade-tariffs-european-union-cars-steel-aluminum-434398.

«H.R.193 - American Sovereignty Restoration Act of 2017.» 3 Ocak 2017. https://www.congress.gov/bill/115th-congress/house-bill/193/text.

Hamilton, Daniel S., ve Joseph P. Quinlan. The Transatlantic Economy 2018. Washington D.C.: Center for Transatlantic Relations, 2018.

Heilbrun, Jacob. «Munich Conference Exposes the Decline of the West.» National Interest. 18 Şubat 2019. https://nationalinterest.org/feature/munich-conferenceexposes-decline-west-44922 (Mart 2, 2019 tarihinde erişilmiştir).

Henriksen, Thomas. Cycles in US Foreign Policy since the Cold War. California: Palgrave Macmillian Press, 2017.

Herring, George. From Colony to Superpower: U.S. Foreign Relations since 1776. New York: Oxford University Press, 2008.

Herszenhorn, David. «Trump dismisses Europe’s trade pitch.» Politico. 6 Haziran 2018. https:/www.politico.eu/article/us-president-donald-trump-dismisses-europes-tradepitch/.

Hooker, R. D.,Jr. The Grand Strategy of the United States. Washington D.C.: National Defense University Press, 2014.

Johnston, Jules. Donald Trump says EU exists to compete with US. 24 Temmuz 2016. https://www.politico.eu/article/donald-trump-says-eu-exists-to-compete-with-usbrexit-nato-wto-nafa/.

«Joined by Allies, President Trump Takes Action to End Syria's Chemical Weapons Attacks.» The White House. 14 Nisan 2018. https://www.whitehouse.gov/ articles/joined-allies-president-trump-takes-action-end-syrias-chemicalweapons-attacks/.

Karnitschnig, Matthew, ve David Herszenhorn. «Münich Insecurity Conference.» Politico. 16 Şubat 2019. https://www.politico.eu/article/munich-securityconference-angela-merkel-mike-pence/ (Mart 2, 2019 tarihinde erişilmiştir). 
Kielinger, Thomas, ve Max Otte. «Germany: The Pressured Power.» Foreign Policy, no. 91 (1993): 44-62.

Kupchan, Charles A. «The Fourth Age: The Next Era in Transatlantic Relations.» The National Interest, no. 85 (2006): 77-83.

LaFaber, Walter. «The US rise to world power, 1776-1945.» US Foreign Policy içinde, yazan Michael Cox ve Doug Stokes, 43-62. Oxford: Oxford University Press, 2008.

Landler, Mark, David E. Sanger, ve Gardiner Harris. Rewrite Iran Deal? Europeans Offer a Different Solution: A New Chapter. 26 Şubat 2018. https://www.nytimes.com/2018/02/26/us/politics/trump-europe-iran-deal.html.

Major, Claudia, ve Christian Mölling. Brexit, Security and Defence: A political problem, not a military one. Stockholm: The Swedish Institute of International Affairs, 2017.

Mandelbaum, Michael. «Pay Up, Europe. What Trump Gets Right About NATO.» Foreign Affairs 96, no. 5 (2017): 108-114.

Mark, Fabian von der. Germany's new strategy to deal with Donald Trump. 24 Ağustos 2018. https://www.dw.com/en/germanys-new-strategy-to-deal-withdonald-trump/a-45217235.

McNeill, William. «Transatlantic History in World Perspective.» Transatlantic History içinde, yazan Steven G. Reinhardt ve Dennis Reinhartz, 3-18. Arlington: Texas A\&M University Press, 2006.

Mearsheimer, John. The Great Delusion: Liberal Dreams and International Realities. New Haven: Yale University Press, 2018.

Morelli, Vincent L., ve Kristin Archick. Transatlantic Relations in 2018. Washington D.C.: Congressional Research Service, 2018.

«Munich Security Report 2019.» Munich Security Conference. 2019. https://www.securityconference.de/en/publications/munich-security-report/ munich-security-report-2019 (Mart 2, 2019 tarihinde erişilmiş̧ir).

«National Defense Strategy of the United States of America.» U.S. Department of Defence. 2018. https://dod.defense.gov/Portals/1/Documents/pubs/2018National-Defense-Strategy-Summary.pdf.

«National Security Strategy of the United States of America.» The White House. Aralık 2017. https://www.whitehouse.gov/wp-content/uploads/2017/12/NSSFinal-12-18-2017-0905-2.pdf. 
NATO. «A Short History of NATO.» 2018. https://www.nato.int/cps/ie/natohq/ declassified_139339.htm.

NATO. «Collective defence - Article 5.» 12 Haziran 2018. https:/www.nato.int/ cps/en/natohq/topics_110496.htm.

NATO. «Funding NATO.» 27 Haziran 2018. https://www.nato.int/cps/en/ natohq/topics_67655.htm.

Nye, Joseph S. «US Power and Strategy After Iraq.» Foreign Affairs, Temmuz/Ağustos 2003.

Özdemir, Çağatay. Amerikan Grand Stratejisi: Obama'nın Ortadoğu Mirası. SETA: İstanbul, 2018.

«Permanent Structured Cooperation (PESCO) - Factsheet.» European Union External Action.19 Kasim 2018. https://eeas.europa.eu/headquarters/headquartersHomepage/34226/permanent-structured-cooperation-pesco-factsheet_en.

Phillips, Carla Rahn. «Economy and Society in the Iberian Atlantic.» Transatlantic History içinde, yazan Steven G. Reinhardt ve Dennis Reinhartz, 19-39. Arlington: Texas A\&M University Press, 2006.

Pifer, Steven. «Is Trump Undoing Trans-Atlantic Relations?» Brookings. 31 Mayls 2017. https://www.brookings.edu/blog/order-from-chaos/2017/05/31/is-trumpundoing-trans-atlantic-relations/.

Pifer, Steven. «The Growing Russian Military Threat in Europe.» Brookings. 17 Mayis 2017. https://www.brookings.edu/testimonies/the-growing-russianmilitary-threat-in-europe/.

Rachman, Gideon. Donald Trump's Unpredictability is Destabilising the World. 22 May1s 2017. https://www.ft.com/content/b56c7c9c-3ecf-11e7-82b6-896b95f30f58.

«Remarks by President Barack Obama in Prague as Delivered.» 2009 Nisan 5. https://obamawhitehouse.archives.gov/the-press-office/remarks-presidentbarack-obama-prague-delivered (Mart 1, 2019 tarihinde erişilmiştir).

Rettman, Andrew. EU Head Calls Trump a 'Threat' to Europe. 31 Ocak 2017. https://euobserver.com/foreign/136742.

Roberts, J. M. Avrupa Tarihi. İstanbul: İnkılap Yayınc1l1k, 2015.

Schultheis, Emily, ve Matthew Karnitschnig. «On transatlantic trade, Trump is all bluster, no bite - so far.» Politico. 17 Kasım 2017. https://www.politico.eu/ article/donald-trump-transatlantic-trade-bluster-no-bite-so-far/. 
Schweiger, Christian. «The "Reluctant Hegemon": Germany in the EU's Post-Crisis Constellation.» The European Union in Crisis: Explorations in Representation and Democratic Legitimacy içinde, yazan Kyriakos Demetriou, 15-32. Springer International Publishing, 2015.

Shapiro, Jeremy, ve Dina Pardijs. The Transatlantic Meaning of Donald Trump: A US-EU Power Audit. London: European Council on Foreign Relations, 2017.

Smith, Mike. «The USA and the EU.» US Foreign Policy içinde, yazan Michael Cox ve Doug Stokes, 236-256. New York: Oxford University Press, 2008.

Sonumut, Güldener. Transatlantik İlişkilerde Yeni Dönem. 27 Mayıs 2017. http://www.milliyet.com.tr/transatlantik-iliskilerde-yeni-dunya-2457773/.

Spy poisoning: Russian diplomats expelled across US and Europe. 26 March 2018. https://www.bbc.com/news/world-us-canada-43545565.

Stelzenmüller, Constanze. Normal is Over. Brookings - Robert Bosch Foundation Transatlantic Initiative, 2018.

Tausendfreund, Rachel. Transatlantic Views on President Trump's First 100 Days in Office. 26 Nisan 2017. http://www.gmfus.org/blog/2017/04/26/transatlanticviews-president-trumps-first-100-days-office.

«The Daedalus European Security: The Interactions of NATO, EU, WEU.» NATO. 2018. https://www.nato.int/acad/fellow/98-00/hatjiadoniu.pdf (Aral1k 18, 2018 tarihinde erişilmiştir).

Trachtenberg, Marc. A Constructed Peace: The Making of the European Settlement, 1945-1963. New Jersey: Princeton University Press, 1999.

Treaty on European Union. Lüksemburg: Office for Official Publications of the European Communities, 1992.

Walt, Stephen. In Praise of a Transatlantic Divorce. 30 Mayis 2017. https://foreignpolicy.com/2017/05/30/in-praise-of-a-transatlantic-divorcetrump-merkel-europe-nato/.

Wickett, Xenia. Transatlantic Relations: Converging or Diverging? London: Chatham House, 2018.

Wright, Thomas. «The Moment the Transatlantic Charade Ended.» The Atlantic. 19 Şubat 2019. https://www.theatlantic.com/ideas/archive/2019/02/mutual-distrust2019-munich-security-conference/583015/ (Mart 2, 2019 tarihinde erişilmiştir). 
